\title{
FOREWORD
}

\section{Aquatic viruses: the emerging story}

\author{
John A. Raven \\ Plant Research Unit, University of Dundee at SCRI, \\ Scottish Crop Research Institute, Invergowrie, Dundee, DD2 5DA, UK. \\ Corresponding author, e-mail: j.a.raven@dundee.ac.uk
}

It is likely that all living organisms can be infected by one or more viruses. One of the latest higher taxa to be converted from 'no characterized viruses' to 'well characterized viruses' are the diatoms (Bacillariophyceae, Heterokontophyta) with the recent publication of three papers characterizing an ssRNA and a ssDNA virus from two genera (Chaetoceros and Rhizosolenia) of marine planktonic diatom (Nagasaki et al., 2004, 2005; Bettarel et al., 2005). It would have been strange if viruses had not been able to exploit the dominant, in terms of global primary production, photosynthetic organisms in the ocean (assimilating perhaps as much as $20 \mathrm{Pg}$ inorganic $\mathrm{C}$ into organic C per year), despite the less than completely convincing arguments assembled by Raven \& Waite (2004) as to possible anti-viral defences unique to diatoms.

The probable ubiquity of viral infection has implications for biodiversity. While viruses fall outside the usual definitions of 'living', they clearly can evolve and they deserve, and have, their own taxonomy and, of course, molecular phylogeny. While viruses are unlikely to attract much interest from, for example, conservation organizations, their (bio?) diversity demands study in its own right and because of their implications for the evolution and functioning of 'real' organisms. These taxonomic and phylogenetic aspects are addressed in a global view in this issue of $7 M B A$ by Munn in his article on viruses of pathogens of marine organisms from bacteria to whales. More specific papers deal with recent work on characterizing viruses of the non-coccolithophore haptophyte Phaeocystis globosa (Wilson et al.) and the diatom Rhizosolenia setigera (Shirai et al.) both members of the Chromista sensu (Cavalier-Smith, 2003) and Heterocapsa circularisquama and other dinoflagellates (Nagasaki et al.) in the Alveolata (Cavalier-Smith, 2003). These papers show, among inter alia, that the phylogeny of viruses does not necessarily map directly onto the phylogeny of the hosts. An example is the work of Wilson et al., who showed that a new virus of Phaeocystis globosa more closely resembles that of other prymnesioviruses infecting Chrysochromulina brevifolium than to the other characterized viruses of Phaeocystis globosa. Furthermore, the paper of Shirai et al. gives the complete genome sequence of the Rhizosolenia setigera virus. Other papers in this issue that have implications for taxonomy and phylogeny of viruses related to bacterial (including cynanobacterial) phages are those of Clokie et al., Jenkins et al., Leitet et al. and McDaniel et al.

The population biology of viruses, and of their hosts, is a rapidly expanding area of research, and has important evolutionary implications for both the viruses and their hosts, as well as for the relative advantage for the virus in infecting the host and for the host in avoiding infection. Work in this area can be found in this issue in the papers by Clokie et al., Gons et al., Hewson \& Fuhrman, Jenkins \& Hayes, Jiao et al., Leitet et al., McDaniel et al., Millard \& Mann, Patten et al., Hewson et al. and Seymour et al. Millard \& Hayes' work in the Baltic Sea follows Hayes' work on the genotypic variability of Nodularia spumigena. Among the more obvious effects of viruses on the population biology of their hosts is in bringing about bloom collapse, as suggested by Wilson et al. (2002) for the coccolithophore Emiliania huxleyi.

Population biology and, when viruses are involved, epidemiology are important inter alia for lateral gene transfer among host genotypes, as noted here for the cyanobacterium Nodularia by Jenkins \& Hayes. This follows earlier demonstrations of genes related to photosynthesis in the genomes of cyanophages infecting marine cyanophytoplankton by Mann et al. (2003), Millard et al. (2004), Bailey et al. (2004), Lindell et al. (2004) and Mann et al. (2005) on Synechococcus spp. and Lindell et al. (2005) on Prochlorococcus marinus. Lindell et al. (2005) showed that these genes produced proteins during host cell infection. Even earlier work by Seaton et al. (1996) on the freshwater phytoplankton green alga Chlorella showed that virus infection increased non-photochemical quenching of chlorophyll fluorescence, and xanthophyll cycle activity. However, this increase in protection against excess excitation energy occurs against a background of a greatly decreased capacity for photosynthesis (Seaton et al., 1995).

Viral lysis of organisms can have a significant impact on the biogeochemical cycle in aquatic habitats. This involves short-circuiting of food webs with less primary productivity consumed by the herbivore food chain, and a more immediate return of the elements in the algae to the microbial loop and to phytoplankton primary productivity (Fuhrman, 1999; Suttle, 2005). This topic is considered in this the special issue by Middelboe \& Jørgensen, who 
provide the first quantitation of free and combined amino acids released by viral lysis of the marine bacterium Cellulophaga sp., and by Seymour et al. in the context of heterogeneity of virus distributions.

One aspect of viral evolution which I find especially interesting are the factors that determine viral burst size, in relation to host factors, as discussed by Brown et al., Gons et al. and by Parada \& Herndl. There are indications that some marine bacteria, including cyanobacteria, have genomes, and cell contents of total nucleic acids and $\mathrm{P}$, which are small enough to limit burst size of (cyano) phages. Genome burst sizes are very significant in that very large burst sizes can extinguish the host community, while very small burst sizes may not be able to sustain the virus population (Mann, 2003). These findings suggest that there could be co-evolution of decreased genome size in (cyano)bacteria as a means of decreasing burst size, with implications for epidemiology at a viral genome size, and decreasing genome size of (cyano)phages (Brown et al.). This idea has also been published independently with much less detail, and by chance with an earlier date, by Raven et al. (2005).

Aquatic virology is clearly an expanding field of research with advances on many fronts, and the papers in this special issue are a very significant contribution to the documentation of these advances.

\section{REFERENCES}

Bailey, S., Clokie, M.R.J., Millard A. \& Mann, N.H., 2004. Cyanophage infection and photoinhibition in marine cyanobacteria. Research in Microbiology, 155, 720-725.

Bettarel, Y. et al., 2005. Isolation and preliminary characterisation of a small nuclear inclusion virus infecting the diatoms Chaetoceros cf. gracilis. Aquatic Marine Ecology, 40, 103-114.

Brown, C.M., Lawrence, J.E. \& Campbell, D.A., 2006. Are phytoplankton population density maxima predictable through analysis of host and viral genomic DNA content? Fournal of the Marine Biological Association of the United Kingdom, 86, 491-498.

Cavalier-Smith, T., 2003. Protist phylogeny and the higher-level classification of Protozoa. European Fournal of Phycology, 39, 338348.

Clokie, M.R.J, Millard, A.D., Mehta, J. \& Mann, N.H., 2006. Virus isolation studies suggest short-term variations in abundance in natural cyanophage populations of the Indian Ocean. Fournal of the Marine Biological Association of the United Kingdom, 86, 499-505.

Fuhrman. J.A., 1999. Marine viruses and their biogeochemical and ecological effects. Nature, London, 399, 541-548.

Gons, H.J., Hoogveld, H.L., Simis, S.G.H. \& Tijdens, M., 2006. Dynamic modelling of viral impact on cyanobacterial populations in shallow lakes: implications of burst size. Fournal of the Marine Biological Association of the United Kingdom, 86, 537-542.

Hewson, I. \& Fuhrman, J.A., 2006. Viral impacts upon marine bacterioplankton assemblage structure. Fournal of the Marine Biological Association of the United Kingdom, 86, 577-589.

Hewson, I., Winget, D.M., Williamson, K.E., Fuhrman, J.A. \& Wommack, K.E., 2006. Viral and bacterial assemblage covariance in oligotrophic waters of the West Florida Shelf (Gulf of Mexico). Fournal of the Marine Biological Association of the United Kingdom, 86, 591-603.

Jenkins, C.A. \& Hayes, P.K., 2006. Diversity of cyanophages infecting the heterocystous filamentous cyanobacterium Nodularia isolated from the brackish Baltic Sea. Fournal of the Marine Biological Association of the United Kingdom, 86, 529-536.
Jiao, N., Zhao, Y., Lou, T. \& Wang, X., 2006. Natural and anthropogenic forcing on the dynamics of virioplankton in the Yangtse river estuary. Fournal of the Marine Biological Association of the United Kingdom, 86, 543-550.

Leitet, C, Rieman, L. \& Hagström, Å., 2006. Plasmids and prophages in Baltic Sea bacterioplankton isolates. Fournal of the Marine Biological Association of the United Kingdom, 86, 567-575.

Lindell, D., Jaffe, D.D., Johnson, Z.I., Church, G.M. \& Chisholm, S.W., 2005. Photosynthesis genes in marine viruses yield proteins during host infections. Nature, London, 438, 86-89.

Lindell, D., Sullivan, M.B., Johnson, Z.I., Tolonen, A.C., Rohwer, F. \& Chisholm, S.W., 2004. Transfer of photosynthetic genes to and from Synechococcus viruses. Proceedings of the National Academy of Sciences of the United States of America, 101, 11013-11018.

MacDaniel, L.D., delaRosa, M. \& Paul, J.H., 2006. Temperate and lytic cyanophages from the Gulf of Mexico. Fournal of the Marine Biological Association of the United Kingdom, 86, 517-527.

Mann, N.H., 2003. Phages of the marine cyanobacterial picophytoplankton. FEMS Letters, 27, 17-34.

Mann, N.H., Cook, A., Millard, A., Bailey, S. \& Clokie M., 2003. Marine ecosystems: bacterial photosynthesis genes in a virus. Nature, London, 424, 741.

Mann, N.H. et al., 2005. The genome of S-PM2, a "photosynthetic" T4-type bacteriophage that infects marine Synechococcus strains. Fournal of Bacteriology, 187, 3188-3200.

Middelboe, M. \& Jørgensen, N.O.G., 2006. Viral lysis of bacteria: an important source of dissolved amino acids and cell wall compounds. Fournal of the Marine Biological Association of the United Kingdom, 86, 605-612.

Millard, A., Clokie, M.R.J., Shub, D.A. \& Mann, N.H., 2004. Genetic organisation of the psbAD region in phages infecting marine Synechococcus strains. Proceedings of the National Academy of Sciences of the United States of America, 101, 11007-11012.

Millard, A.D. \& Mann, N.H., 2006. A temporal and spatial investigation of cyanophage abundance in the Gulf of Aquaba, Red Sea. Journal of the Marine Biological Association of the United Kingdom, 86, 507-515.

Munn, C.B., 2006. Viruses as pathogens of marine organismsfrom bacteria to whales. Fournal of the Marine Biological Association of the United Kingdom, 86, 453-467.

Nagasaki, K., Tomura, K., Katanozaka, N., Nishida, K., Itakura, S. \& Yamaguchi, M., 2004. Isolation and characterization of a novel single-stranded RNA virus infecting the bloom-forming diatom Rhizosolenia setigera. Applied and Environmental Microbiology, 70, 704-711.

Nagasaki, K., Tomaru, Y., Shirai, Y., Takao, Y. \& Mizumoto, H., 2006. Dinoflagellate-infecting viruses. Fournal of the Marine Biological Association of the United Kingdom, 86, 469-474.

Nagasaki, K., Tomaru, Y., Takao, K., Shirai, Y., Suzuki, H. \& Nagumo, T., 2005. Previously unknown virus infects marine diatom. Applied and Environmental Microbiology, 71, 3258-3535.

Parada, V., Herndl, G.J. \& Weinbauer, M.G., 2006. Viral burst size of heterotrophic prokaryotes in aquatic systems. Fournal of the Marine Biological Association of the United Kingdom, 86, 613-621.

Patten, N.L., Seymour, J.R. \& Mitchell, J.G., 2006. Flow cytometric analysis of virus-like particles and heterotrophic bacteria within coral-associated reef water. Fournal of the Marine Biological Association of the United Kingdom, 86, 563-566.

Raven, J.A., Finkel, Z.V. \& Irwin, A.J., 2005. Picophytoplankton: bottom-up and top-down controls on ecology and evolution. Vie et Milieu, 55, 209-215.

Raven, J.A. \& Waite, A., 2004. The evolution of silicification in diatoms: inescapable sinking and sinking as escape? New Phytologist, 162, 45-61.

Seaton, G.G.R., Hurry, V.M. \& Rohozinski, J., 1996. Novel amplification of non-photochemical chlorophyll fluorescence quenching following viral infection in Chlorella. FEBS Letters, 389, 319-323. 
Seaton, G.G.R, Lee, K. \& Rohozinski, J., 1995. Photosynthetic shutdown in Chlorella NC64A associated with the infection cycle of Paramecium bursa Chlorella virus-1. Plant Physiology, 108, 1431-1438.

Seymour, J.R., Seuront, L., Doubell, M., Waters, R.L. \& Mitchell, J.G., 2006. Microscale patchiness of virioplankton. Fournal of the Marine Biological Association of the United Kingdom, 86, 551-561.

Shirai, Y., Takao, Y., Mizumoto, H., Tomaru, Y., Honda, D. \& Nagasaki, K., 2006. Genomic and phylogenetic analysis of a single-stranded RNA virus infecting Rhizosolenia setigera (Stramenopiles: Bacillariophyceae). Fournal of the Marine Biological Association of the United Kingdom, 86, 475-483.
Suttle, G.A., 2005. Viruses in the sea. Nature, London, 437, 356-361.

Wilson, W.H., Schroeder, D.C., Ho, J. \& Canty, M., 2006. Phylogenetic analysis of PgV-102P, a new virus from the English Channel that infects Phaeocystis globosa. Fournal of the Marine Biological Association of the United Kingdom, 86, 485490.

Wilson, W.H., Tarran, G.A., Schroeder, D., Cox, M., Oke, J. \& Malin, G., 2002. Isolation of viruses responsible for the demise of an Emiliania huxleyi bloom in the English Channel. Fournal of the Marine Biological Association of the United Kingdom, 82, 369-377. 